\title{
Internalization of Indonesian Language as a Critical Thinking Development Effort in Character Formation
}

\author{
Liesna Andriany \\ Faculty of Teachers Training and Education, Universitas Islam Sumatera Utara, Medan, Indonesia \\ liesna.andriany63@gmail.com; liesna.andriany@fkip.uisu.ac.id \\ ${ }^{*}$ Corresponding Author
}

How to Cite: Andriany, L. (2019). Internalization of Indonesian Language as a Critical Thinking Development Effort in Character Formation. International Journal for Educational and Vocational Studies, 1 (7), 787-790

\section{ARTICLE HISTORY}

Received: 3 August 2019

Revised: 13 September 2019

Accepted: 28 October 2019

\section{KEYWORDS}

\section{Internalization;}

Indonesian Language;

Learning Strategies;

Critical Thinking;

\section{ABSTRACT}

Indonesian language courses are compulsory for every student. The purpose of this study is to describe the Indonesian language learning strategy by internalizing Indonesian language education in the development of critical thinking. Critical thinking criteria using FRISCO from Ennis. This research is qualitative with research instruments using observation, questionnaires, interviews, documentation, and tests. Whereas the data analysis technique following Miles and Huberman is done by data reduction and continuous data presentation. Data validity uses data triangulation. The findings show that the critical thinking skills of students on average meet the UISU National Standards. Development of a project-based Indonesian learning strategy that is tailored to the material. The process of internalizing Indonesian education emphasizes critical thinking skills in character building. Proven project-based Indonesian learning strategies can hone students' critical thinking skills so that student character education is formed.

\section{INTRODUCTION}

Indonesian is the unitary language of the Republic of Indonesia stipulated in the 1945 Constitution. The latest regulation on the use of Indonesian was issued Presidential Regulation no 63 of 2019 This Perpres needs to be issued to anticipate the effects of globalization. Globalization has positive and negative impacts for the people of Indonesia. The positive impact can be felt and enjoyed together, such as; Rapid information flow is not distinguished by time and space. Likewise with the negative impacts, one of which is happening right now is that Indonesian people lose their identity, especially the use of Indonesian language and forget about character education. In fact, Indonesian is a characteristic of the Indonesian nation and character education really needs to be instilled starting from children to students. Violence, fights, killings, sexual harassment now occur starting from the victim to the perpetrators from elementary school level to college students. This is due to the influence of globalization where the people are "godly" materialistic, so there is an imbalance between economic development and character development. Campus is a place to process to open minds and insight into the horizons of the thinking of its citizens. The world of campus is a world that is expected to provide a positive direction and can break down progress in Indonesia. Campus is not only a producer of science and technology, but also the world of campus is expected to be able to bridge changes in everything so that Indonesia can stand in line with developed countries in the world. An important need that must be had by every individual in this globalization era is the skill critical thinking. Based on interviews with lecturers, the results are $100 \%$ that this critical thinking skill is the most important skill. However, in the educational process students are not given the opportunity to build their critical thinking framework, and often do not become the main concern for lecturers. This paper aims to answer the question of how to internalize Indonesian language learning in an effort to improve students having critical thinking skills in character building.

\section{METHODS}

\subsection{Type of Research}

This research is a qualitative research with the case study being students of the Faculty of Medicine of the North Sumatra Islamic University (UISU) Medan who received Indonesian language courses with a total of 55 students. The time spent in this study is 1 semester. The research sample is total sampling. Research instruments in the form 
of questionnaires, written tests, observation sheets and interviews. The questionnaire aims to capture the extent to which the Indonesian language learning strategies undertaken by lecturers make students eager to attend lectures. The written test used is an objective test to measure the cognitive level of students in solving problems in the form of objective tests. The observation sheet is designed to capture data on students' critical thinking behavior when learning is carried out. Interviews are used to strengthen the findings of written tests and observations. Data analysis techniques refer to Hubermen (2007) with steps, data collection, data reduction, data presentation, and finally drawing conclusions. To measure the validity of the data triangulation of data is done by triangulation of methods in which the test data, observation, and interviews are compared so that valid data is obtained.

\subsection{Data Collection Techniques from Critical Thinking by Internalization of Indonesian Language Subjects}

One of the university courses is Indonesian, which is given for only one semester and weighs 2 SKS (Semester Credit Units) in each study program. This little time does not only mean the cognitive aspects that are the focus, but also the psychomotor aspects, and the affective aspects. Just how lecturers use time as efficiently and effectively as possible to optimize the achievement of Indonesian language learning in tertiary institutions. To achieve the achievements of Indonesian language learning, one of the learning strategies used in Indonesian language learning is project-based methods. The steps of implementing this project-based learning strategy basically depart from inquiry (inquiry learning), problem-based learning (problem solving learning), and discovery learning (discovery learning) strategies. Broadly speaking, the implementation is planning (creating), creating (implementing or implementing, and processing) (Mahanal, 2009). Through internalization of Indonesian courses in the process of learning Indonesian by using project-based strategies, it can improve students' critical thinking skills In project-based strategy, lecturers and students create two-way communication, in other words learning is no longer focused on the teacher but student centered learning (student center learning) Indicators to see critical thinking skills are used indicators proposed by Ennis (2011) that the skills Critical thinking of students can be seen in the criteria and indicators abbreviated with FRISCO (Focus, Reason, Inference, Situation, Clarity, and Overview).

\section{RESULTS AND DISCUSSION}

In Based on a questionnaire distributed with questions revolving around lecturer teaching strategies and character education. The results of the questionnaire found that students felt less interested in Indonesian language learning as much as 54\%, attended the lessons only because of $23 \%$ obligation, and went to college because of the demands of attendance, $7 \%$ and only $16 \%$ were really to gain their knowledge. The results of the questionnaire showed that $100 \%$ of students agreed that character education was important and had competence in character education. The results of the questionnaire showed that students were not interested in taking the lessons because they felt they were not interested in learning Indonesian, this resulted in the transfer of knowledge and critical thinking processes not as expected.

Next, the research was carried out by applying a project-based learning strategy in the Indonesian language class. The learning steps that are applied are based on inquiry inquiry, problem solving learning, and discovery learning strategies. Broadly speaking the implementation is planning (planning), creating (creating or implementing, and processing (processing).

The initial stage is planning, this stage is the beginning in the implementation of learning so that the lecturer prepares the assignment in advance and explains the learning objectives to the students. At this stage students are assigned to search for and find problems related to the use of Indonesian and real phenomena. The problems found will later become their respective projects. Furthermore, students discuss to arrange the design of activities that they will do to complete their project. It is at this stage that critical thoughts are expected from them to come up with bright ideas. Next, lecturers and students make an agreement together to finish their project.

The second stage is the creation, in this second stage students are required to put out their critical thoughts to provide creative ideas in completing the agreed project assignments. At present the lecturer must actively monitor by using an observation sheet assessing students' attitudes in critical thinking, as well as providing the guidance needed by students. The ideas put forward respectively are collected and then developed and documented. After students report the results of their project assignments, then the lecturer gives feedback on their understanding and work results.

Finally, the processing stage, the last stage the students then present the results of their project findings in class together with other groups. Presentation of the results of this project aims to communicate and exchange opinions in presenting ideas and group ideas. Finally, the evaluation phase is conducted by the lecturer together with students. Lecturers and students reflect the results that have been obtained both individually and in groups. In this evaluation phase, the lecturer gives an assessment achieved by students both in groups and individually. Evaluation includes cognitive, affective, and psychomotor. While the evaluation given by students is more on providing opportunities for students to convey their experiences in completing projects for the next improvement aspects. 
Table 1. Result of Student Critical Thingking Ability Tests

\begin{tabular}{clccc}
\hline No & \multicolumn{1}{c}{ Lecture material } & Critical Thinking & Criteria Percentage of Material & Achievement Information \\
\hline 1 & History Position, and Function of Indonesian Language & FRISCO & $56.71 \%$ & Does not meet SN UISU \\
\hline 2 & The Choice of Words Diction & FRISCO & $67.54 \%$ & Did not meet SN UISU \\
\hline 3 & Indonesian Spelling of & FRISCO & $78.48 \%$ & Meet SN UISU \\
\hline 4 & Paragraph & FRISCO & $85.27 \%$ & Has Fullfilled the SN UISU \\
\hline 5 & Effective Sentence & FRISCO & $93.65 \%$ & Already met SN UISU \\
\hline 6 & Writing Scientific papers & FRISCO & $87.56 \%$ & Fullfilled SN UISU \\
\hline
\end{tabular}

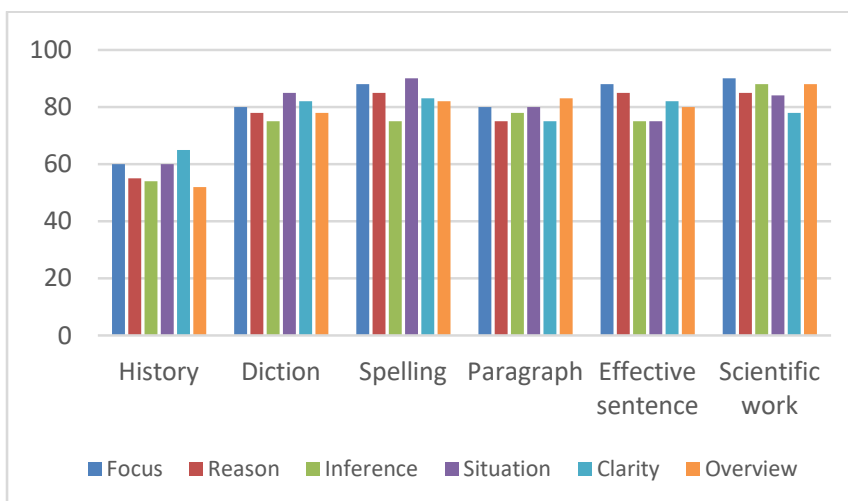

Figure 1. Critical Thinking Test

Critical thinking test results seen in the table above show that in the material 'History, position, and function of Indonesian language' students have not gotten the maximum results in mastering the material, still $56.71 \%$ who achieved the UISU National Standard (SN UISU), this meaning that there are $43.29 \%$ more that do not meet the criteria of SN UISU. From the results of interviews with students it is known that they do not feel interested, and catching the strategies carried out only adds to their learning burden. The results of observations in the class also showed that students' interest in doing assignments was very low, even there was a tendency to ignore assignments. There are still many students who do not participate. This is because students are not accustomed to exchanging knowledge during discussions.

In the next material, the results of the study showed a significant increase, the criteria of critical thinking of FRISCO in UISU students illustrated that the criteria of focus with indicators of students were able to concentrate on existing problems and could make questions to look for problems. This criterion is the forerunner in determining the activities to be performed. Reason criteria with student indicators are able to provide reasons with mastery of theory and facts and can make conclusions and decisions. Inference Criteria with student indicators are able to provide accurate data to be able to prove that decisions and conclusions made can be justified. Situation Criteria with indicators students are able to see and adjust to the situation so that the sources and information according to needs. Clarity criteria with student indicators are able to explain and explain to be considered in analyzing the results of deduction. Finally the Overview criteria with indicators students are able to reconsider and review the conclusions or decisions. Judging from the percentage of material achievements shows increased mastery. The material presented is in accordance with the syllabus of Indonesian language courses $67.54 \%$, Indonesian Spelling $78.48 \%$, Paragraph $85.27 \%$, Effective Sentences $93.65 \%$, Writing Scientific Papers 87.56\% have fulfilled SN UISU. Cognitive mastery means having the ability to accept, analyze, and respond to a phenomenon. Furthermore, after analyzing data from the cognitive abilities of Indonesian language material to measure students' critical thinking skills through critical thinking tests, data from observations, interview data, and questionnaires compared to the results of data triangulation, the results are obtained as in the following graph.

\section{CONCLUSION}

This From Figure above it is known that the first meeting with the material 'History of Indonesian still shows critical in the sense of the five criteria of critical thinking FRISCO has not been satisfactory. Students have not been able to focus or ask about activities that must be done to solve problems, are still weak in giving reasons, still lacking in providing data to support decisions, still unable to adjust to the right information, but are able to explain the consideration of deduction results, and very lack of ability to consider the conclusions. At the meeting that discusses the 'diction' students have begun to meet the expected criteria. The meeting that discusses the material 'Spelling' of students is weak in inference, meaning students are still less able to provide strong evidence about the spelling used. But in the material 'paragraphs' all the criteria decreased from the meeting in the previous material, although still the results are satisfactory. This is because students are not accustomed to writing and reading, so it is difficult to write a paragraph. In the material 'effective sentence' has returned very well, only those that still lack inference and situation. Finally, the material on 'scientific work' 'clarity' is less than the other criteria for critical thinking, but still very satisfying. This is because students are still unable to explain the results of the analysis in more detail.

From the analysis it is known that it is known that project-based strategies have advantages in improving students' critical thinking skills. With this strategy students are more active and lecturers are not too burdened because learning is centered on students. During the discussion students share ideas and students are free to develop innovative ideas. Students interact with each other while honing their minds to think critically. Students can make conclusions well. Thus it can be said that the indicator of critical thinking of students is very good. 


\section{REFERENCES}

Ahmad,D., Marimba. (2014). Pendidikan Anak. Tarsito, Bandung.

Andriany, (2014). Pengembangan Model Pendidikan Karakter. (Studi tentang Pendidikan Karakter di UISU). Laporan Penelitian

Angelo, Thomas A. \& Cross. Patricia. (1995). Classroom Assessment Techniques: A Handbook for Colege Teachers, $2^{\text {nd }}$ edition.

Brookhart, Susan M \& Nitko. A.J. (2008). Assessment and Grading in Classrooms. Upper Saddle River, N.J: Pearson Education

Ennis, R.H. (2011). The Nature of Critical Thinking: An Outline of Critical Thinking Dispositions and Abilities (online). Hhtp://faculty.ed.uiuc.edu/rhennis/documents/TheNa tureofCriticalThingking_51711_000.pdf (04 Januari 2018).

Kilpatrick, William Heard, (1957). Philosophy of Education, New York: Mac. Millan

Kunarto, Ninik M. (2007). Cermat dalam Berbahasa, Teliti dalam Berpikir. Jakarta: Mitra Wacana Media.

Lambertus. (2009). Pentingnya Melatih Keterampilan Berpikir Kritis dalam Pembelajaran Matematika di SD. Forum Kependidikan, 28(2): 136-142

Linckona, T. (1991). Educating for Character: How Our Schools can Teach Respect and Responsibility. New York: Bantam Books.

Mahanal. S. (2009). Pengaruh Pembelajaran Project Based Learning pada Materi Ekosistem terhadap Sikap dan Hasil Belajar Siswa SMAN 2 Malang. Jurnal Sains. 1-10

Miles, Mattew B dan A. Michael Huberman. 2007. Analisis Data Kualitatif, Buku Sumber tentang Metode-Metode Baru. Jakarta: Universitas Indonesia Press

Mochtar Buchori, (2007). Character Building dan Pendidikan Kita. (http://w.w.w. Kompas.co.id/kompas-cetak/0607/26/opini/2836169.h tm). Diunduh 27 November 2010.

United National Depelopment Programme (UNDP). 2014. Laporan Indeks Pembangunan Manusia Indonesia 2014

Peraturan Presiden Nomor 63 Tahun 2019 tentang Penggunaan Bahasa Indonesia

Undang-Undang Republik Indonesia tahun 2003. Tentang Sistem Pendidikan Nasional 